\title{
ELEMENTS OF OPEN PUBLIC SPACE AT CORRIDOR SOMBAOPU STREET MAKASSAR CITY
}

\author{
Sriany Ersina \\ Jurusan Teknik Arsitektur \\ Fakultas Sains dan Teknologi UIN Alauddin Makassar \\ J1. Sultan Alauddin No. 63, Kabupaten Gowa, Sulawesi Selatan. 92113 \\ E-mail: sriany.ersina@uin-alauddin.ac.id
}

\begin{abstract}
Physical elements forming characters in the corridor Somba Opu street Makassar city such as trees/shade, diversity of buildings, street furniture, open space, accessibility, density, contrast, parking, pedestrian pathways, and pavement are still considered to be less supportive of characteristics and strengthen the identity of the corridor area the street. In this case the physical elements still give the impression of being neglected on several corridor Somba Opu street Makassar city, besides that improper arrangement and processing of elements can also affect the convenience of visitors in shopping or users of the corridor Somba Opu street Makassar city, giving rise to responses from community groups to the physical elements in the corridor. From this background, the formulation of the problem in this study is the extent of the influence of the physical elements forming the character of the corridor Somba Opu street Makassar city, and which physical elements dominate the character formation of the corridor Somba Opu street Makassar city, according to the community response. This paper is intended to analyze and find out the physical elements that dominate the character formation of the street corridor that automatically affects the characteristics that already exist on the corridor Somba Opu street Makassar city based on the response from the community. In this study, it is based on a quantitative and qualitative paradigm which will compare the response of the community to the physical elements forming the street character. The method in this study was through questionnaires and interviews with community groups (shop owners, street users/visitors, and street vendors) to find out their responses to the physical elements that make up the character in the corridor Somba Opu street Makassar city, and then obtain the data analyzed with the help of the SPSS program with discriminant techniques. The results of this study indicate the element of accessibility that dominate the formation of the corridor Somba Opu street Makassar city corridor character, according to the response from the community (shop owners, users/visitors, and street vendors).
\end{abstract}

Keywords: Elements Public Spaces, Characteristics, Corridors.

\section{INTRODUCTION}

1 $\mathrm{s}$ the provincial capital of South Sulawesi, Makassar has several commercial areas or trade centers with distinctive characteristics and different service scales. One form of trade/trade area is in the form of a "shopping street" which implies the space used for something. Where the meaning of shopping (shopping) means buying, visiting shops to make purchases and see goods (the store in question is a building or space where goods or services are sold to the public), and street itself originates from the Latin "sternere" which means coating, it implies the limitation of the surface and the marking made in open space which then becomes the concept of the street hierarchy. So overall shopping street is a street that is limited to one or both sides by a store that has an entrance (entrance) on the inside edge of the pavement, and a storage room and access to goods on the back facing a street/service line.

Some shopping streets in Makassar have started to develop with quite high trade intensity, one of which is shopping street which is on Somba Opu street. The place to shop is on the Somba Opu street, namely: 1. Souvenir/souvenir shops from Makassar-South of Sulawesi, etc., 2. Restaurant, and 3. Street vendors/informal sector 
Shopping street on Somba Opu street has supporting elements that should be able to support the function and strengthen the identity of the area or corridor of the street. Some elements that are considered important include: pedestrian ways, street furniture, parking, signage (billboards/ advertisements), skyline, enclosures (boundaries), and style (architectural style). This is explained by Allan B. Jacob (1993) in his book "Great Street", that a street with strong character is seen more because of its design characteristics and physical condition; and supported by John A. Jakle (1987) in his book "The Visual Element of Landscape" that the visual element of the landscape that gives characteristics to a place, can be seen from; scale, seeing in detail from the street scale/observation; Pavement material, street furnishing, and vegetation, style, as well as the face / face of the building.

However, seeing the reality on the corridor Somba Opu street in the form of care, processing, and structuring of the physical elements is less attention. This affects the characteristics of the corridor Somba Opu street, which causes chaos and unkempt appearance, besides the improper arrangement and processing of elements can also affect the convenience of visitors to shop or Somba Opu street users. In accordance with the formulation of the problem above, the objectives of this study are to find out how the community responds to the character building physical elements that are in the corridor Somba Opu street Makassar city. Also to find out the physical elements that dominate character formation on the corridor Somba Opu street Makassar city, based on responses from the community.

This research, in general, is expected to be a reference for the Makassar City Government in determining the strategy for the development and development of corridors in Somba Opu Street Makassar City. This study is specifically expected to be able to: (i) Providing knowledge about the physical elements that dominate character formation towards the characteristics of the corridor Somba Opu street Makassar city, based on responses from the community. (ii) Become input for other prospective researchers who will conduct research with a substantial scope of research similar to this research.

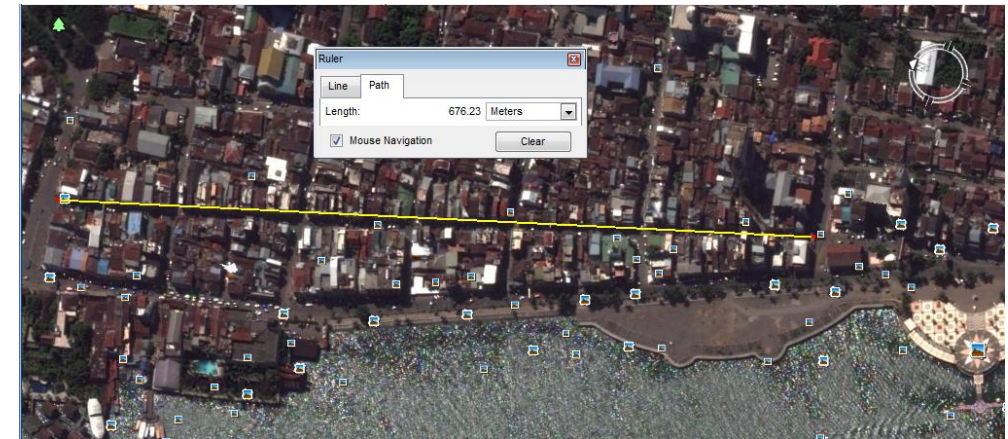

Figure 1. Top view corridor Somba Opu street (Source: Google Earth, 2015)

In the Kamus Besar Bahasa Indonesia (2007), the characteristics are a distinctive sign that distinguishes something from others. And streets are land transportation infrastructure covering all parts of the street, including complementary buildings and equipment intended for traffic, which are on the surface of the land, above the surface of the land, below the surface of the land and/or water, and above the water surface, except railstreet, lorry, and cable streets. So the characteristics of the street are land transportation infrastructure that has its own characteristics or signs, in this case, different from the others. In this study, it refers to the theory of Allan B. Jacob (1993); pedestrian ways, street furniture, parking, signage (billboards/advertisements), skyline, enclosures (boundaries), and style (architectural style). The addition of several other supporting theories from John A. Jakle (1987); scale, seeing in detail from the street scale/observation; Pavement material, street 
furnishing, and vegetation, style, as well as the face/face of the building. Corridor overview Somba Opu Street Makassar can be seen in Figure 1.

Based on the division of the Makassar City Region, corridor Somba Opu street is in the City Territory. The functions of the City Region Section are as follows: (a) Settlement; (b) Trade and services; (c) College; (d) Industry and (e) Transportation. Corridor Somba Opu street Makassar city is classified as a secondary local street with local regulations that apply including Building Base Coefficient 60\%, Building Height 1 - 4 floors, and Building Floor Coefficients 1 - 2.4, and Building Border Lines 17 meters (Makassar City Spatial Planning).

\section{MATERIAL AND METHODS}

In this study based on the quantitative and qualitative paradigm (Iskandar, 2008), then in this study will compare the response of the community to the physical elements forming the street character. The method in this study was through questionnaires and interviews with community groups (shop owners, users/visitors, and street vendors) to find out their responses to the physical elements that make up the character in the corridor Somba Opu Street Makassar city, and then obtain the data analyzed with the help of the SPSS program with discriminant techniques. The sample in this study are street vendors (informal sector) who sell along the corridor Somba Opu street, shop/business owners (formal sector) along the corridor Somba Opu street, as well as, and visitors/users of the corridor Somba Opu street. The determination of the number of samples developed by Rascoe in Sugiyono (2005). The sample size for the study was 100 people in each category, from 8:00 am to 21:00, Monday to Sunday.

\section{RESULTS AND DISCUSSION}

\section{Physical Elements Forming the Somba Opu Makassar Corridor}

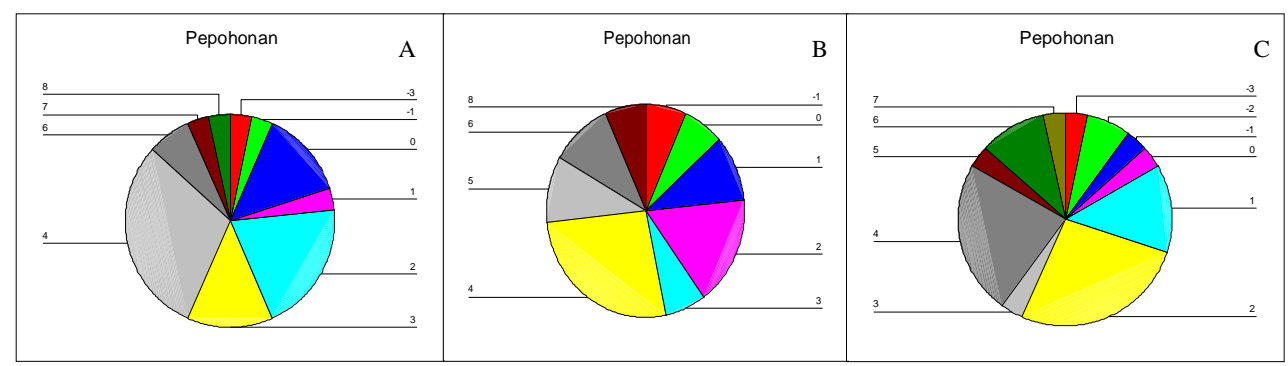

Figure 2. Element of Trees: A. Street vendors (informal sector) response to elements of trees/shade nature (grey: 30\%); B. Shop/business owners (formal sector) response to elements of trees/shade nature (yellow: $26.7 \%$ ); Visitors/users owners response to elements of trees/shade nature (yellow: 26.7\%).

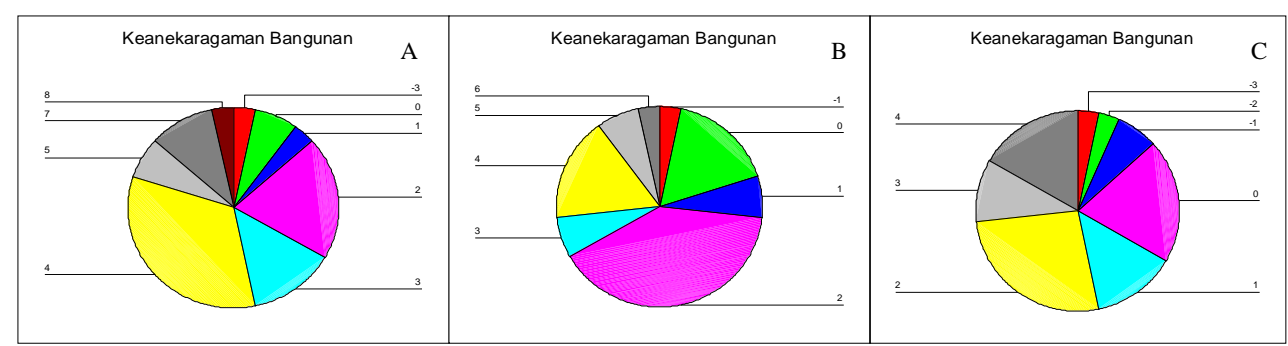

Figure 3. Elements of Building Diversity: A. Street vendors response to the element of Building Diversity (yelloe: 33\%); B. Shop/business owners response to the element of Building Diversity (pink: 40\%); Visitors/users response to the element of Building Diversity (yellow: 26.7\%). 


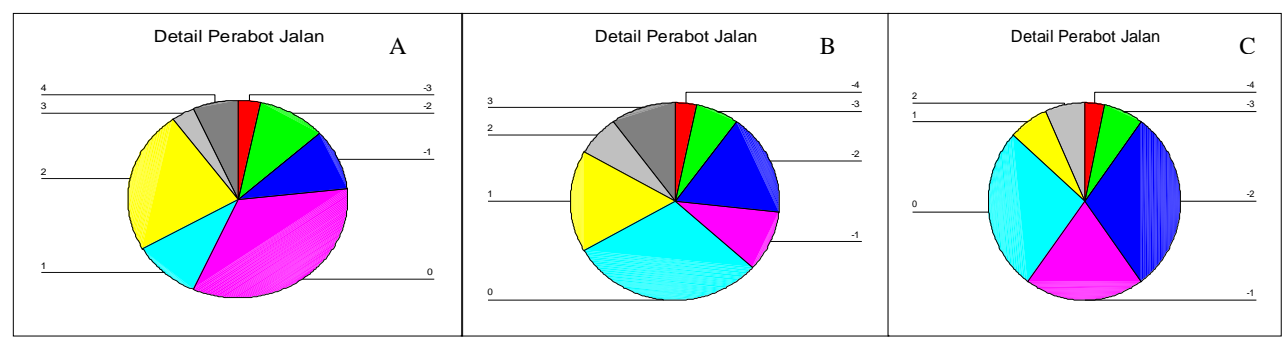

Figure 4. Elements of Street Furniture: A. Street vendors response to the element of Street Furniture (pink: 33.3\%); B. Shop/business owners response to the element of Street Furniture (tosca: 30\%); Visitors/users response to the element of Street Furniture (blue: 30\%).

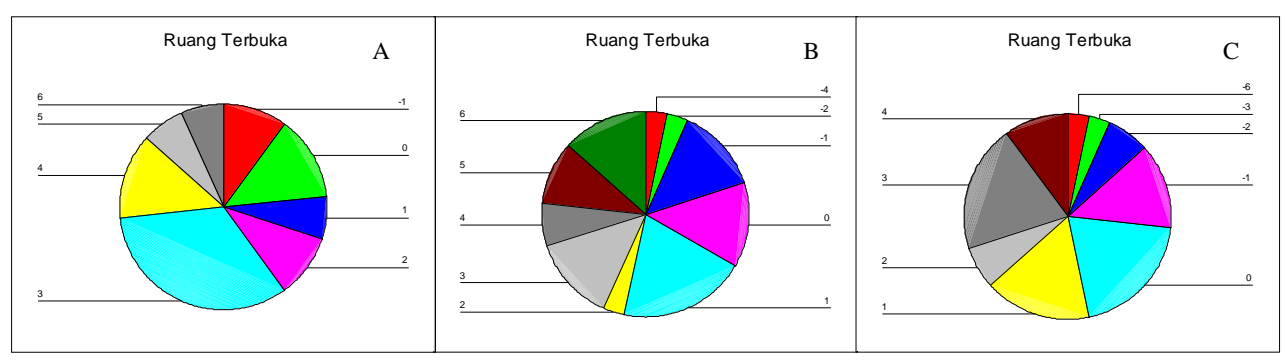

Figure 5. Elements of Open Space: A. Street vendors response to the element of Open Space (tosca: $33.3 \%$ ); B. Shop/business response to the element of Open Space (tosca: 20\%); Visitors/users response to the element of Open Space (tosca: 20\%).

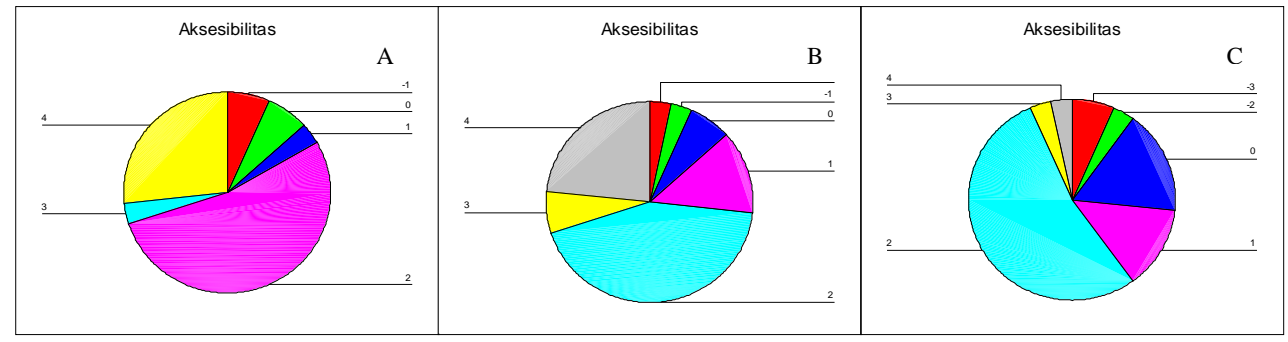

Figure 6. Elements of Accessibility: A. Street vendors response to the element of Accessibility (pink: 53.3\%); B. Shop/business response to the element of Accessibility (tosca: 43.3\%); Visitors/users response to the element of Accessibility (tosca: 53.3\%).

Element of density on this study shows street vendors response (strongly agree) to the element of density is about $26.7 \%$, shop/business response to the element of density $23.3 \%$ and visitors/users response (strongly agree) to the element of density is about $40 \%$. Then elements of contrast is followed by $30 \%$ street vendors response (strongly agree) to the element of contrast, $36.7 \%$ of shop/business response (strongly agree) to the element of contrast, and $40 \%$ visitors/users response (neutral) to the element of contrast. The next data shown element of parking showed about $46 \%$ street vendors response (neutral) to the element of parking, shop/business response to the element of parking about $36.7 \%$ (disagree), and visitor $65.5 \%$ (disagree). Element of pedestrian way showed $40 \%$ street vendors rensponse (strongly agree) to the element of pedestrian way, and the last is element of pavement about $27.6 \%$ of street vendors response (disagree) to the ement of pavement. 
Table 1. Summary of analysis \& discussion of physical character forming elements

\begin{tabular}{|c|c|c|c|}
\hline $\begin{array}{l}\text { Physical Forming Character } \\
\text { Elements }\end{array}$ & According to street vendor Responses & According to the Shop Owner Response & According to the User/Visitor Response \\
\hline Tree Elements & $\begin{array}{l}\text { Trees; dominant gives a positive response of } \\
\text { 30.0\%, because it considers trees can provide } \\
\text { shade for them. For more details, the trees } / \\
\text { shelters that are on the street are considered to } \\
\text { have not provided shade, therefore the street } \\
\text { vendors appear in the afternoon; precisely around } \\
\text { 17.30pm WITA. }\end{array}$ & $\begin{array}{l}\text { Trees; dominant gave a positive response of } \\
26.7 \% \text {, because it was considered to provide } \\
\text { shade and form like a fence / barrier that } \\
\text { lined neatly to the Somba Opu Makassar } \\
\text { street, so it looked better than other streets } \\
\text { around the area. }\end{array}$ & $\begin{array}{l}\text { Trees; dominant gives a positive response of } 26.7 \% \text {, } \\
\text { because it is considered to be able to provide shade, } \\
\text { especially when their vehicles are parked as well as a } \\
\text { beautiful view on the street of Somba Opu Makassar } \\
\text { because it looks like a straight line. }\end{array}$ \\
\hline Elements of Building Diversity & $\begin{array}{l}\text { Building Diversity; dominant gives a positive } \\
\text { response of } 333.3 \% \text {, because it is considered to } \\
\text { provide its own characteristics for the Somba Opu } \\
\text { Makassar street, where the characteristics here are as } \\
\text { a typical Sulawesi hawker center and Noble Gold / } \\
\text { metal. }\end{array}$ & $\begin{array}{l}\text { Building Diversity; dominant gives a positive } \\
\text { response of } 40.0 \% \text {, because it is considered to } \\
\text { provide its own character for the Somba Opu } \\
\text { Makassar street, namely the character as a } \\
\text { hawker center with various building forms; } \\
\text { both shop houses, restaurants, and street } \\
\text { vendors on the street. }\end{array}$ & $\begin{array}{l}\text { Building Diversity; dominant gives a positive } \\
\text { response of } 26.7 \% \text {, because it considers the diverse } \\
\text { buildings provide many choices of needs for them; } \\
\text { starting from basic needs to secondary needs. }\end{array}$ \\
\hline Elements of Street Furniture & $\begin{array}{l}\text { Street Furniture; dominant gives a neutral response } \\
\text { of } 33.3 \% \text {, because it is considered trees / shade, } \\
\text { paving, street lighting, traffic lights, street signs, } \\
\text { bulletin boards, billbards, trash bins, plants with } \\
\text { pots and kiosks / street vendor stalls on Somba Opu } \\
\text { Makassar street are neatly arranged. }\end{array}$ & $\begin{array}{l}\text { Street Furniture; dominant gives a neutral } \\
\text { response of } 30.0 \% \text {, because there are } \\
\text { considered to be neatly arranged and there are } \\
\text { still some that have not been neatly arranged. } \\
\text { Understand them about street furniture; in } \\
\text { addition to street tights, ibllbaards, trash bins, } \\
\text { plants with pots, the street vendors / stalls are } \\
\text { on the Somba Opu street in Makassar. }\end{array}$ & $\begin{array}{l}\text { Street Furniture; dominant gave a negative response } \\
\text { of } 30.0 \% \text { (strongly disagree, because it was } \\
\text { considered not at all neatly arranged. }\end{array}$ \\
\hline Elements of Open Space & $\begin{array}{l}\text { Open Space ; dominant gives a positive response } \\
\text { of } 33.3 \% \text {, because it is considered open space like } \\
\text { a corridor street which has its own characteristics } \\
\text { of the Somba Opu Makassar street. }\end{array}$ & $\begin{array}{l}\text { Open Space ; dominant gives a positive } \\
\text { response of } 20.0 \% \text {, because it is considered to } \\
\text { give its own characteristics of existing } \\
\text { characteristics. }\end{array}$ & $\begin{array}{l}\text { Open Space; dominant gives a positive response of } \\
20.0 \% \text {, because it is considered to give its own } \\
\text { characteristics to the characteristics of the Somba Opu } \\
\text { Makassar street. }\end{array}$ \\
\hline Elements of Accessibility & $\begin{array}{l}\text { Accessibility; dominant gives a positive response of } \\
53.3 \% \text {, because it is considered snacks that they } \\
\text { serve are easily reached by users / visitors to Somba } \\
\text { Opu Makassar. }\end{array}$ & $\begin{array}{l}\text { Accessibility; dominant gives a positive } \\
\text { response of 53.3\%, because it is considered } \\
\text { snacks that they serve are easily reached by } \\
\text { users/visitors to Somba Opu Makassar. }\end{array}$ & $\begin{array}{l}\text { Accessibility; dominant gave a positive response of } \\
53.3 \%, \text { because it was considered able to easily reach } \\
\text { all of their needs, or in other words all they wanted } \\
\text { was already on the street to Somba Opu Makassar. }\end{array}$ \\
\hline Element of Density & $\begin{array}{l}\text { Density; dominant gave a positive response of } \\
26.7 \% \text {, because the snacks they sell can be used up } \\
\text { quickly by users / visitors to Somba Opu Makassar. }\end{array}$ & $\begin{array}{l}\text { Density; dominant gives a positive response } \\
\text { of } 23.3 \% \text {, because it is considered to be able } \\
\text { to sell well their merchandise. }\end{array}$ & $\begin{array}{l}\text { Density; dominant gives a positive response of } 40.0 \% \text {, } \\
\text { because it is considered density on the Somba Opu } \\
\text { Makassar street is dense with a typical Sulawesi } \\
\text { hawker center and Precious Gold / Metals. }\end{array}$ \\
\hline Elements of Contrast & $\begin{array}{l}\text { Contrast: dominant gives a positive response of } \\
30.0 \% \text {, because it is considered to give its own } \\
\text { characteristics for the Somba Opu Makassar street, } \\
\text { where understanding the contrast of character is } \\
\text { more about the typical Sulawesi and Gold / Precious } \\
\text { Metal snacks on the street. }\end{array}$ & $\begin{array}{l}\text { Contrast: dominant gives a positive response } \\
\text { of } 36.7 \% \text {, because it is considered to give its } \\
\text { own characteristics for the street of Somba } \\
\text { Opu Makassar, where understanding the } \\
\text { contrast of the character is forming an overall } \\
\text { street pattern. }\end{array}$ & $\begin{array}{l}\text { Contrast: dominant gives a positive response of } \\
40.0 \% \text {, because it is considered to provide its own } \\
\text { characteristics for the Somba Opu Makassar street. } \\
\text { Where the contrast characteristics in question are } \\
\text { trading activities dominated by Sulawesi specialty } \\
\text { snacks and Gold / Precious Metals. }\end{array}$ \\
\hline Elements of Parking & $\begin{array}{l}\text { Parking; dominant gives a positive response of } \\
46.4 \% \text {, because it considers parking facilities } \\
\text { already available on Somba Opu Makassar and has } \\
\text { been neatly arranged. }\end{array}$ & $\begin{array}{l}\text { Parking; dominant gives a negative response } \\
\text { of } 36.7 \% \text {, because it is considered not neatly } \\
\text { organized and still chaotic. Uncluttered } \\
\text { parking will prevent access to their stores, so } \\
\text { potential buyers who will shop at their store } \\
\text { will look for other stores. }\end{array}$ & $\begin{array}{l}\text { Parking; dominant gave a negative response of } 65.5 \% \text {, } \\
\text { because it was considered not yet neatly arranged and } \\
\text { still chaotic, and reduced street use capacity so that it } \\
\text { was prone to traffic jams on Somba Opu Makassar } \\
\text { street. }\end{array}$ \\
\hline Element of Pedestrian Way & $\begin{array}{l}\text { Pedestrian way; dominant gives a positive response } \\
\text { of } 40.0 \% \text {, because it is considered good and no one } \\
\text { ever feeld disturbed and complains about the state of } \\
\text { the pedestrian path they use. }\end{array}$ & $\begin{array}{l}\text { Pedestrian way; dominant gave a negative } \\
\text { response of } 23.3 \% \text {, because it was considered } \\
\text { not functioning properly. }\end{array}$ & $\begin{array}{l}\text { Pedestrian way; dominant gives a neutral response of } \\
36.7 \% \text {, in this case it does not justify the condition of } \\
\text { the pedestrian path that is not functioning properly } \\
\text { because indeed the track conditions are still bumpy } \\
\text { and uncomfortable to be crossed by pedestrians so } \\
\text { that the path is used by street vendors. }\end{array}$ \\
\hline Elements of Pavement & $\begin{array}{l}\text { Pavement; dominant gives a positive response of } \\
34.5 \%, \text { because it is considered neat and very } \\
\text { comfortable to be crossed by pedestrians and } \\
\text { motorized vehicles. }\end{array}$ & $\begin{array}{l}\text { Pavement; dominant gives a neutral response } \\
\text { of } 33.3 \% \text {, because it considers the condition } \\
\text { of pavement is not so neat, but so far it is still } \\
\text { quite comfortable to be crossed by } \\
\text { pedestrians and motorized vehicles. }\end{array}$ & $\begin{array}{l}\text { Pavement; dominant gave a negative response of } \\
53.6 \% \text {, because it was considered not neat and very } \\
\text { uncomfortable to be crossed by pedestrians or } \\
\text { motorized vehicles. }\end{array}$ \\
\hline
\end{tabular}
rees; dominant gives a positive response of are on the street are considered ting, traffic lights, street sig (a) to be crossed by pedestrians an pedestrians and motorized vehicles

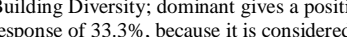

\section{Conclusion}

rees on the Somba Opu Makassar street have been shown to provide shade according to the theory of Rubeinstein (1992) which states that trees offer the best control over solar radiation and can block sunlight or shade can be a natural system that soothes the air. Where this theory supports the theory of Jacob which states that trees / shelters are most effective in improving street quality, this is also evident on the Somba Opu
Makassar street where the existing trees / shade are adjacent to each other, creating a row of columns that Makassar street where the existing trees / shade are adjacent to each other, creating a row of columns tha
visually and psychologically separate between the path of the vehicle \& street. the diversity of buildings on the Somba Opu Makassar street provides additional characteristics of the characteristics that already exist on the street. Where the additional characters in question are permanent buildings from the formal sector with a floor of 1-2 / more, and added with semi-permanent buildings from the informal sector (street vendors / street vendors) to form a skyline line that can generate interest. This is in

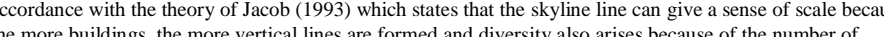
buildings rather than a few buildings in an area or street corridor.

street furniture on the Somba Opu Makassar street is more to street vendors / stalls on the street. So the theory of acob (1993) states that seating encourages people to stay, invites the presence of the community by providing a place to rest, taik, wait for friends, or just spend time, in other words seating encourages the community to go to

open space on the Somba Opu Makassar street provides more character than the characteristics that already exi breaker becomes more important in narrow and long street conditions and on curved and turned streets because the breaker can give a stop, rest and becowit a refrence point along he way. Accessibility on the Somba Opu Makassar street is more convenient for visitors / street users. In this case street users who drive and are physically fit. While the ease of access for people with disabilities is not yet available on
the street at all. As explained by Jacob (1993) that accessibility is related to the ease of access of the general street has a ramp. So for the Somba Opu Makassar street, facilities are only for street users who drive and are physically fit, but are not suitable for people with disabilities.

The etsity on Somba Opu Makassar street is more to the informal sector (PKL) with the visitors / users of the sreet. This is in accordance with the theory of Jacob (1993) that activities on the street increase when high
density is the density of buildings and the density of activities. Varied land use also stimulates many activities hat are prerequisites for survival from the street (Moughtin, 1992).

The contrast in Somba Opu Makassar can be seen from the physical design conditions in the street corridor (1) create an attractive and creative environment. Where this theory supports the theory of Jacob (1993) which states hat contrast in street design is what makes a street different from the others, which makes one path the best, contrasts include the shape, length, size or overall pattern of the stree.

Parking on the Somba Opu Makassar street has not been neatly arranged because there is still no adequate parking facilities on the street. This is not in accordance with the theory of Moughtin (1992) which states that the
por integration between parking spaces of vehicles with the whole street. People who drive vehicles will prefer to
nark their vehicles as close to their destination as possible, the best is in front of their destination. This is what park their vehicles as close to their destination as possible, the best is in front of their destination. This is what appened on Somba Opu Makassar, where vehicles automatically parked close to street vendors or shop

The pedestrian way on Somba Opu street Makassar city is not functioning properly because the track condition are still uncomfortable to be crossed by pedestrians in this case it is still bumpy and hollow. So the theory of Jacob (1993) explains that good streets have walking places that provide space for people to carry out walking com fortably in this case neatly arranged; not corrugated and not perforated, and equipped with street furnitre, proven on the street Somba Opu Makassar.

The pavement on Somba Opu Makassar street is not yet neat and very uncomfortable to be crossed by

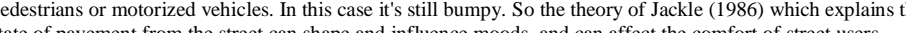
where the pavement can be used to divide large areas, very precisely because the still bumpy Somba Opu Makassar especially street users complain about. 


\section{CONCLUSION}

The research conclusions regarding the elements of open public space at corridor sombaopu street makassar city are as follows: 1 . Physical elements forming characters: Element of Trees/shade on Somba Opu street Makassar city provide shade for street users/visitors, shop owners, especially for street vendors. Elements of Building Diversity; provide additional characters from the characteristics that already exist on the Somba Opu street Makassar city. Element of Street Furniture; some are neatly arranged and some are not neatly arranged. Where street furniture on the Somba Opu street Makassar city is not only trees, paving, street lighting, traffic lights, street signs, billboards, billboards, trash bins, plants with pots, also stalls street vendors on the street. Element of Open Space like streets actually has its own characteristics of the characteristics that already exist on the Somba Opu street Makassar city. Element of Accessibility on the Somba Opu street Makassar city received more positive responses because they were easily reached by visitors to the street. Element of Density on the Somba Opu street Makassar city receives a positive response because the density on the street is more on the informal sector (at night \& holidays) with visitors on the street. Element of Contrast can be seen from the physical design conditions on the corridor Somba Opu street Makassar city which predominantly forms a strong character from the existing characteristics of the corridor Somba Opu street Makassar city as the Shopping Street Center. Element of Parking is still not neatly arranged, because there is no parking facility on corridor Somba Opu street Makassar city. Element of Pedestrian on the corridor Somba Opu street Makassar city have not functioned properly because the track conditions are still uncomfortable to be crossed by pedestrians, in this case, it is still bumpy and hollow. Element of Pavement on corridor Somba Opu street Makassar city is not yet neat and very uncomfortable to be crossed by pedestrians or motorized vehicles. In this case, it's still bumpy. 2) Physical Elements on the Characteristics of Corridor Somba Opu street Makassar city. There are significant relationships and influences between the physical elements forming the character and characteristics of the corridor Somba Opu street Makassar city. The last, the most influential physical element is Element of Accessibility.

\section{REFERENCES}

Alwi, H \& Tim (Pusat Bahasa). (2007). Kamus Besar Bahasa Indonesia. Jakarta: Balai Pustaka.

Arikunto, S. (1995). Prosedur Penelitian. Jakarta: Rineka Cipta.

Bungin, B. (2005). Metodologi Penelitian Kuantitatif, Jakarta: Kencana Prenada Media Group

Government Regulation of the Republic of Indonesia Number 26 of 1985 concerning Streets.

Granham, H.L. (1970). Maintaining The Spirit of Place, Process for The Preservation of Town Character. Meza Arizona: PDA Publisher Co.

Hakim, R. (2003). Konsep Perancangan Arsitektur Lansekap. Jakarta: Balai Pustaka.

Haryadi, B. S. (1995). Arsitektur Lingkungan dan Perilaku, Jakarta: Direktorat Jenderal Pendidikan Tinggi Departemen Pendidikan dan Kebudayaan.

Iskandar. (2008). Metodologi Penelitian Pendidikan dan Sosial (Kuantitatif dan Kualitatif). Jakarta: GP (Gaung Persada) Press. 
Jacobs, A.B. (1993). Great Streets. Cambridge: MIT Press.

Jakle, J.A. (1987). The Visual Elements of Landscape. United States of America (USA):

The University of Massachusetts Press, John Willey and Sons Inc.

Law of the Republic of Indonesia Number 38 of 2004 concerning Streets.

Moughtin, C. (1992). Urban Design, Street and Square. Oxford: Butterworth Heineman Ltd, Linacrehouse, Oxford.

Muhadjir, N. (1989). Metodologi Penelitian Kualitatif: Telaahan Positivistik Rasionalistik dan Phenomenologik. Yogyakarta: Rake Sarasin.

Rubeinstein, H.M. (1992). Pedestrian Mall, Streetscape and Urban Space. New York:

Sangarimbun, M., \& Efendi, Sofyan. (1989). Metode Penelitian Survei. Jakarta: LP3ES.

Simamora, B. (2005). Analisis Multivariat Pemasaran. Jakarta: Penerbit PT. Gramedia Pustaka Utama.

Sugiyono. (2005). Metodologi Penelitian Administrasi. Bandung: CV. Alfabeta.

Sukirman, S. (1999). Dasar-dasar Perencanaan Geometrik Jalan. Bandung: Penerbit Nova.

Weisman, J. (1981). Modelling Environment Behavior System. Journal of Man Environmental Relation.

Zahnd, M. (1999). Perancangan Kota Secara Terpadu: Teori Perancangan Kota dan Penerapannya. Yogyakarta: Penerbit Kanisius. 